J. E. Guest - P. D. Spudis · R. Greeley

G. J. Taylor - S. M. Baloga

\title{
Emplacement of xenolith nodules in the Kaupulehu lava flow, Hualalai Volcano, Hawaii
}

Received: October 14, 1994 / Accepted: March 21, 1995

\begin{abstract}
The basaltic Kaupulehu 1800-1801 lava flow of Hualalai Volcano, Hawaii contains abundant ultramafic xenoliths. Many of these xenoliths occur as bedded layers of semi-rounded nodules, each thinly coated with a veneer (typically $1 \mathrm{~mm}$ thick) of lava. The nodule beds are analogous to cobble deposits of fluvial sedimentary systems. Although several mechanisms have been proposed for the formation of the nodule beds, it was found that, at more than one locality, the nodule beds are overbank levee deposits. The geological occurrence of the nodules, certain diagnostic aspects of the flow morphology and consideration of the inferred emplacement process indicate that the Kaupulehu flow had an exceptionally low viscosity on eruption and that the flow of the lava stream was extremely rapid, with flow velocities of at least $10 \mathrm{~m} \mathrm{~s}^{-1}$ (more than $40 \mathrm{~km} \mathrm{~h}^{-1}$ ). This flow is the youngest on Hualalai Volcano and future eruptions of a similar type would pose considerable hazard to life as well as property.
\end{abstract}

Key words lava flows - xenoliths - nodule beds . levee deposits - Hualalai Volcano, Hawaii

\section{Kaupulehu lava flow and its xenoliths}

The historical 1800-1801 eruption of Hualalai Volcano, Hawaii was spectacular in many ways. Eyewitness reports indicate that the eruption produced a voluminous

J. E. Guest (ब)

University of London Observatory.

ULO Annexe and Planetary Image Centre,

33-35 Daws Lane, London NW7 4SD. UK

P. D. Spudis

Lunar and Planetary Institute, Houston, TX 77058-1113, USA

R. Greeley

Arizona State University, AZ 85287-1404, USA

G. J. Taylor

University of Hawaii, Honolulu. HI 96822, USA

S. M. Baloga

Proxemy Research Inc., Laytonsville, MD 20882, USA flow and the lava rapidly inundated several villages, destroyed plantations and overwhelmed fishponds (Ellis 1842). Several alkali basalt flow fields were produced from vents with altitudes ranging from 500 to $1890 \mathrm{~m}$. The Kaupulehu flow and the smaller Huehue flow, which erupted from a separate and lower vent on Hualalai's main northwest rift (Fig. 1; Moore and Clague 1991), together make up the largest volume of this eruptive episode on Hualalai volcano.

The Kaupulehu flow began about midway up the north-west rift zone of Hualalai at an elevation of about $1700 \mathrm{~m}$ above sea level (Fig. 1). The source area consists of several craters, fissures and collapse pits, ranging in size from a $250 \mathrm{~m}$ diameter crater that appears to have held a lava lake, to Kaupulehu Crater itself, a lava-veneered cinder cone about $100 \mathrm{~m}$ in diameter. The vent area of the flow is mantled with fine lapilli, some of which occur in beds up to $2 \mathrm{~m}$ thick. The eruption occurred from a zone of fissures that strike north-west, roughly parallel to and on the rift zone. The Kaupulehu flow is more than $15 \mathrm{~km}$ long from vent to sea and has an average slope of $6.5^{\circ}$ (Fig. 1); however, it can be divided into four slope 'zones', being steepest near the vent area (a zone $3 \mathrm{~km}$ long having a $12.5^{\circ}$ slope) and flattest near the end where it enters the sea (a zone $2.5 \mathrm{~km}$ long having a $1.2^{\circ}$ slope).

At about $1 \mathrm{~km}$ elevation above sea level is a telecommunications repeater station (Fig. 1). The flow in this area occurs on a broad, topographic fan-like mound that appears to have been formed by earlier eruptions at this site. It displays several pits, channels, spatter cones and other vent-like features (Jackson and Clague 1982), as well as a network of near-vertical shafts, fissures and subterranean chambers. We have not yet determined whether this area is the primary vent for the Kaupulehu flow, or a 'rootless' vent, serving to discharge lava to the surface after being transported by a tube system from upslope on the rift zone.

The Kaupulehu lava flow is best known for its beds of ultramafic, xenolithic nodules. These nodules are 

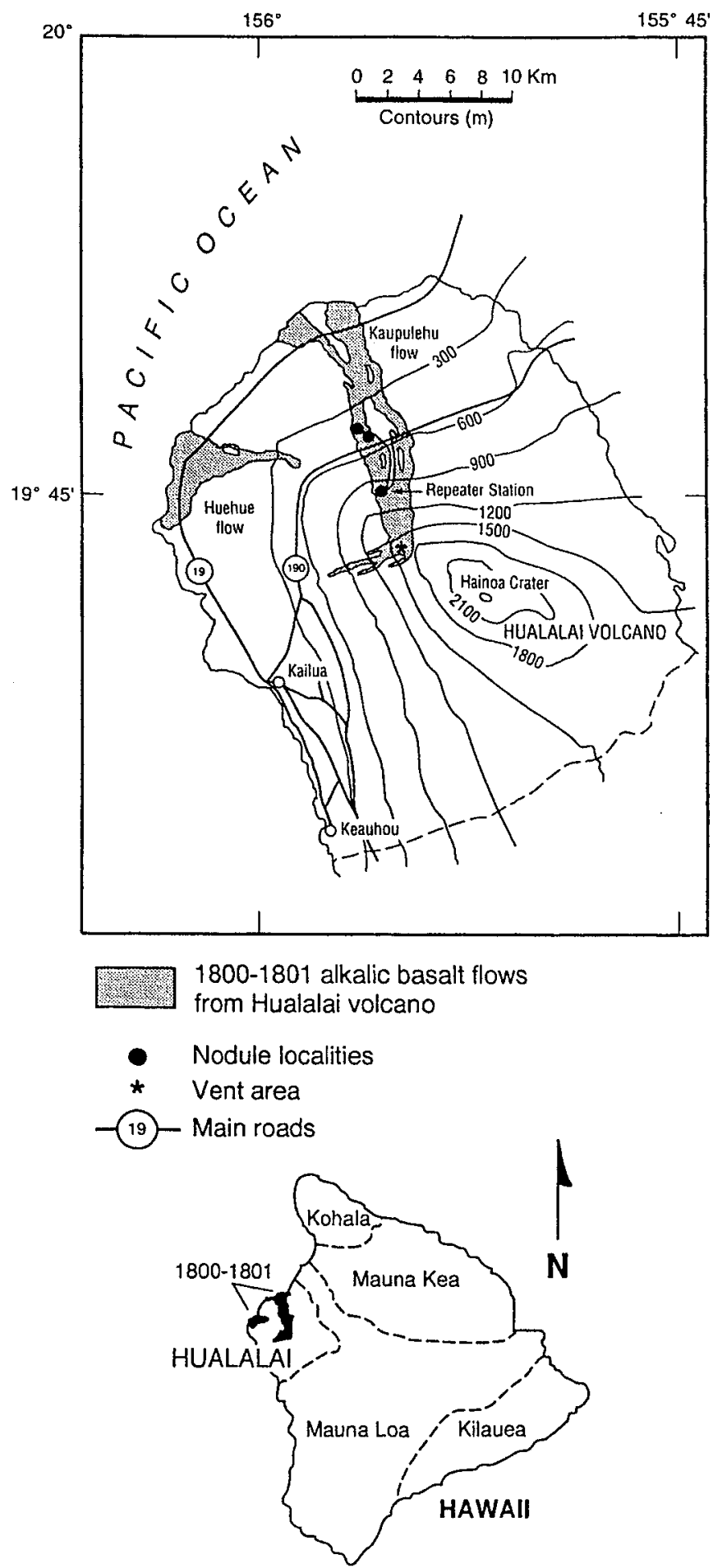

Fig. 1 Map of Hualalai Volcano. Hawaii showing the 1800-1801 flows and locations of known beds of xenolith nodules. Inset shows the geographical relations between Hualalai and the other volcanoes on the island of Hawaii. After Moore et al. (1987)

coated with a thin (normally about $1 \mathrm{~mm}$ or less, more rarely up to several mm thick) veneer of lava (Richter and Murata 1961; Jackson et al. 1981; Jackson and Clague 1982; Moore et al. 1987). The nodules are dominantly subangular and consist of dunite and wehrlite

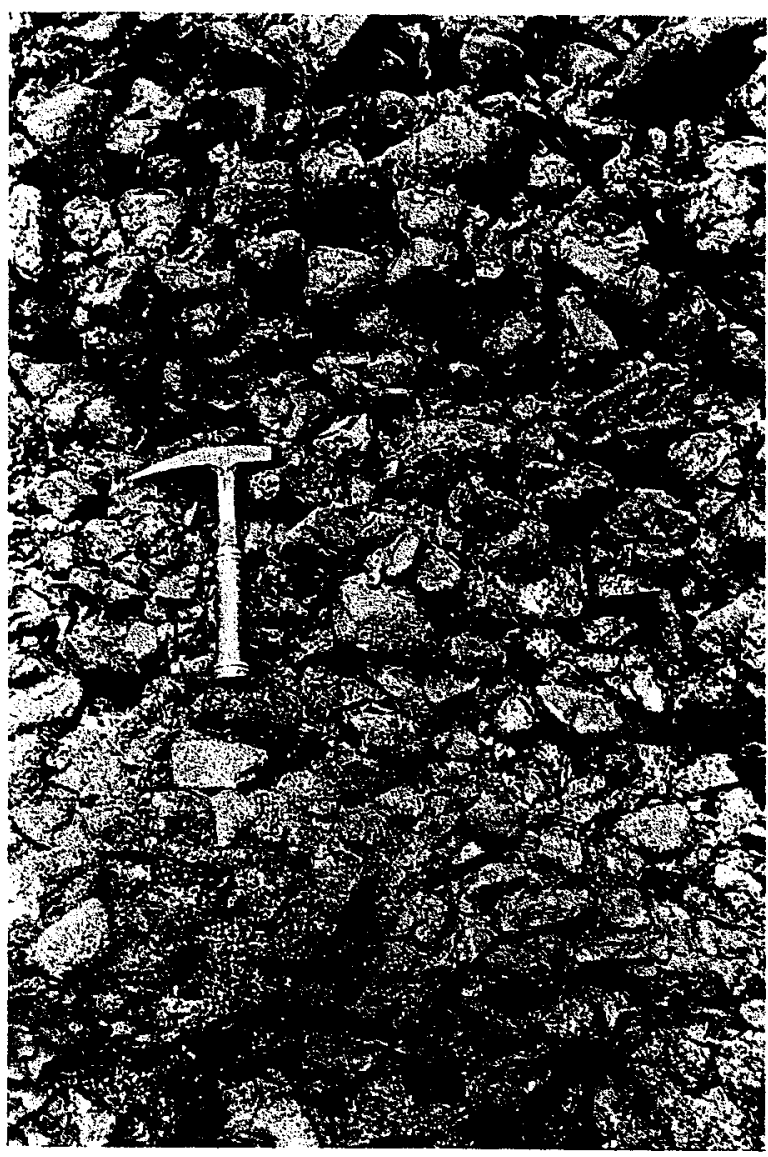

Fig. 2 Xenolith nodule bed of the 1801 Kaupulehu flow showing thin veneer of lava on each xenolith. Lava has drained from the stack of nodules

(with minor amounts of websterite, gabbro, anorthosite and troctolite), ranging typically from 10 to $50 \mathrm{~cm}$ in maximum dimension and having densities mostly between 3100 and $3300 \mathrm{~kg} \mathrm{~m}^{-3}$ (Jackson et al. 1981), greater than the average $2600 \mathrm{~kg} \mathrm{~m}^{-3}$ density of the host basalt. These nodules and less abundant, scattered xenoliths within the Kaupulehu flow are thought to be materials derived from just below the base of the crust, at a range of depths between 13 and $28 \mathrm{~km}$ below sea level (Bohrson and Clague 1988; Chen et al. 1992). Although xenoliths suspended in lava are distributed throughout the flow, at certain localities they occur as bedded banks of nodules from which lava has drained away (Figs. 1 and 2). In this paper, we use the term nodule solely to refer to xenoliths that have thin coats of lava and are found in beds at these localities.

The mechanism of ascent and emplacement of the xenoliths has been discussed by several workers. For the Kaupulehu flow, McGetchin and Eichelberger (1975) argued that a rapid rate of magma ascent was required to carry dense nodules to the surface. Their calculations, which indicated rates of magma flow through the conduit of $10-15 \mathrm{~m} \mathrm{~s}^{-1}$. assumed that the magma had Newtonian rheology (McGetchin et al. 1976). However, for basaltic lava flows in general, it 
Fig. 3 Cross-sections illustrating contrasting models of nodule emplacement by Richter and Murata (1961) on the left and Jackson and Clague (1982) on the right
N

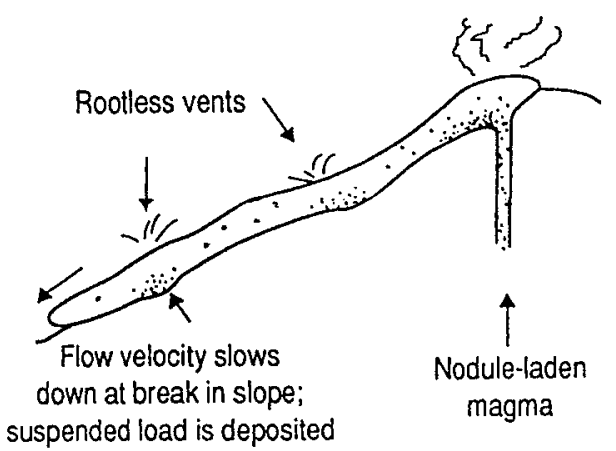

suspended load is deposited

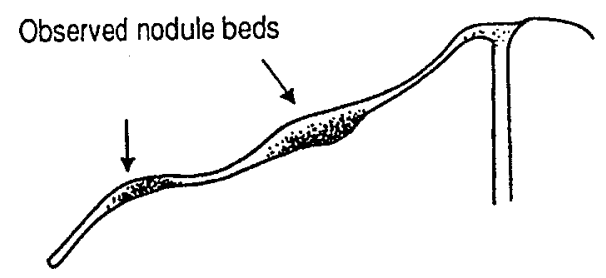

Final form
$N$
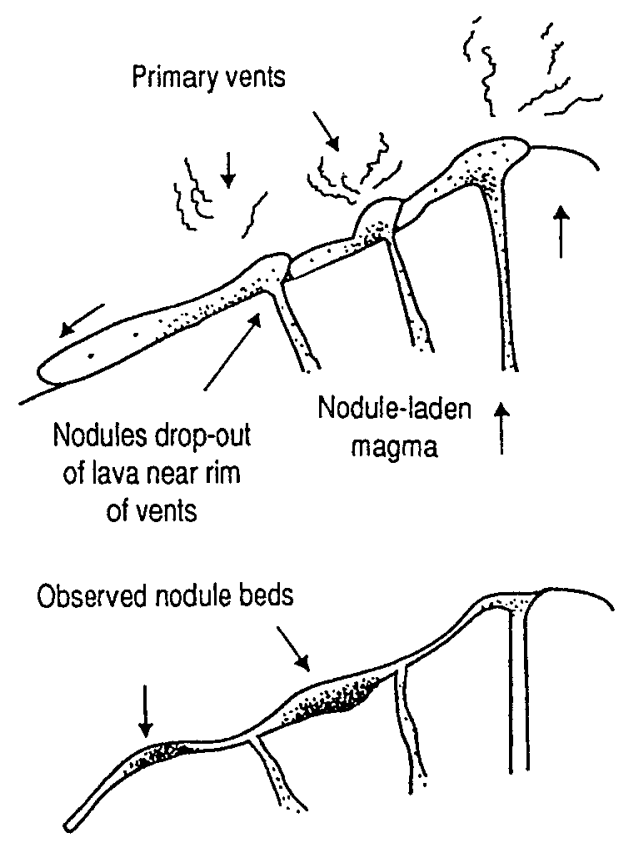

Final form was argued by Sparks et al. (1977) that such high ascent rates are not required if the magma is non-Newtonian and thus better able to support the relatively dense inclusions. Although this argument for a Bingham flow rheology may be correct for many xenolith occurrences elsewhere in the world, field observations of the stacks of nodules in the Kaupulehu flow show an almost complete drainage of the host lava, leaving only a thin $(\sim 1 \mathrm{~mm}$ ) veneer of basalt on the nodules (Fig. 2; Richter and Murata 1961). The significance of these thin veneers is that if the lava was non-Newtonian, the thin rinds indicate that the yield strength, or viscosity at low rates of shear, was extremely low. If, on the other hand, the lava was Newtonian, then stored heat from the nodules would help maintain the temperature of the host lava and the slower rates of cooling would allow the lava to drain away. In any event, these observations indicate that the fluid dynamic behavior of the host lava during both eruption and emplacement involved Newtonian, or close to Newtonian, rheology.

Several mechanisms for the emplacement of the nodules have been proposed (Fig. 3). The nodules may have been deposited as a lag where the flow encountered topographic benches on the slopes of Hualalai volcano, thus reducing the velocity of the flow and allowing suspended nodules to be deposited (Richter and Murata 1961). Alternatively, the nodules may have dropped out of the flow as lava emerged from vents. forming a near-vent lag deposit (Fig. 3; Jackson and Clague 1982). Yet another possibility is that a lava tube feeding the flow became blocked with nodules, causing lava to erupt from skylights carrying the nodules with it (Bohrson and Clague 1988; D. A. Clague, personal communication 1992). Although not necessarily reject- ing these previous ideas, we identify here another mechanism for producing banks of nodules.

\section{Nodule levees}

The distribution of known nodule beds in the Kaupulehu flow is indicated in Fig. 1. Extensive accumulations of nodules occur near the communication repeater station, about $5 \mathrm{~km}$ from the uppermost fissure vent, at an elevation of about $1 \mathrm{~km}$ above sea level (Jackson and Clague 1982; Fig. 4a). This area appears to be one in which lava was erupted either from primary vents (i.e. through fissure-fed dikes that connect to the north-west rift system of Hualalai; Moore et al. 1987), or as rootless vents where lava broke out of an underlying tube system. Several deep pits are evident here; subsurface exploration shows that these pits are the surface expression of a complex, interconnected underground network. The subsurface chambers are lined with banks of xenolith nodules and their walls are coated by xenolith-bearing lava up to $50 \mathrm{~cm}$ thickness.

South of and uphill from the repeater station is a short lava channel, about $35 \mathrm{~m}$ across and about $150 \mathrm{~m}$ long (Fig. 4). At its eastern end it appears to be associated with a pit from which lava was erupted; its western end is blocked by piles of nodules from which lava has drained to produce collapse pits. The present floor of the channel consists of late-stage pahoehoe flows which left three lava benches as the flow drained away downhill. These late-stage flows have characteristics typical of those formed from a lava with basaltic rheology and, by themselves, are not indicative of any unusual eruptive properties. 


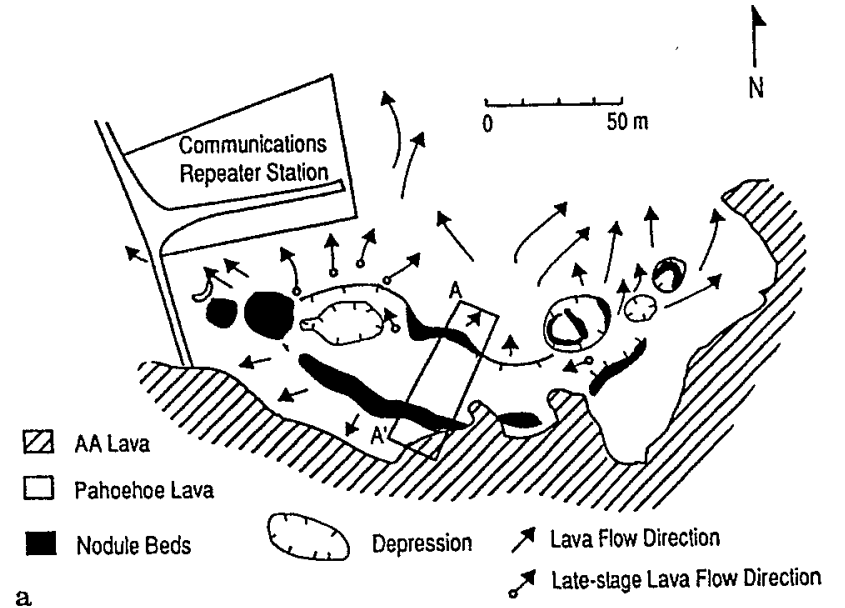

$A^{*}$

A

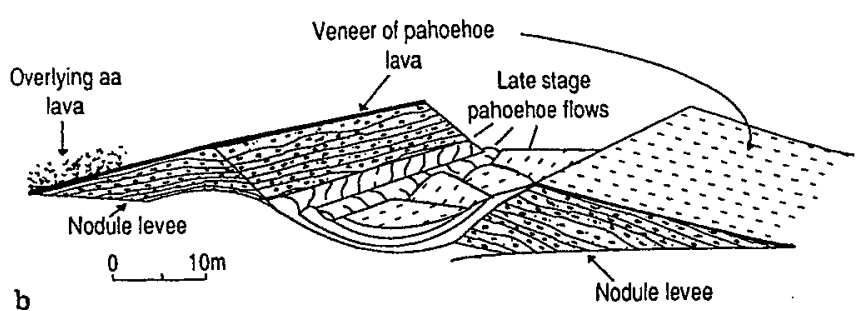

Fig. 4 a Sketch map showing lava channel and nodule beds near communications repeater station. Outline box shown as block diagram in b. After Jackson and Clague (1982). b Block diagram $\left(\mathrm{A}-\mathrm{A}^{\prime}\right)$ of the channel and nodule beds (outline of area shown in Fig. 4a) showing nodule levees. The nodule bed is thinly veneered by pahoehoe lava

However, this channel is bounded by nodule banks. The banks stand about 3-5 $\mathrm{m}$ above the channel floor and consist of crudely bedded nodules. The nodules are each typically about $10 \mathrm{~cm}$ in diameter and form beds $30-50 \mathrm{~cm}$ thick (Figs. 4 and 5). Individual nodules are coated with a thin (up to about $1 \mathrm{~mm}$ thick) layer of lava. The nodules are loosely welded together by this lava veneer and small stalactites of lava are seen on the lower parts of the nodules, representing the last stages of flow drainage from between the nodules. The nodule banks dip away from the axis of the channel, although in some places there is an inward inclination to the channel side of the beds, suggesting back-flow. The nodule bank is capped by vesicular pahoehoe lava, 3$25 \mathrm{~cm}$ thick; on the western side of the channel, the lava that veneers the bank surface displays embedded xenoliths.

We interpret this structure as an overflow levee. During the eruption, the channel was bankfull of flowing lava and contained many suspended nodules. When overflows occurred, nodules were deposited on the surface of the bank, owing to a reduction of flow velocity and subsequent drainage of the host lava. On the basis of this model, we interpret many of the nodule beds exposed in this area and elsewhere in the flow as having been formed as levees bounding a flow that frequently overtopped its banks. At one locality, the nodule banks occur on the inside parts of bends where the velocity of lava flow may have been reduced, in a manner similar to preferential deposition on the interior bends of rivers (e.g. Allen 1970).

Nodule beds occur over a considerable length of the flow, as far as $4 \mathrm{~km}$ beyond the repeater station site toward the ocean (Fig. 1). Although the deposition of nodules was most likely to occur where the velocity of the flow was reduced, our model of overbank levees explains more readily why all of the xenoliths that were entrained in the magma were not deposited from the flow in the same place, as would probably occur if they were emplaced simply as a result of the main flow losing velocity (e.g. Richter and Murata 1961). Our proposed mechanism predicts substantial accumulation of nodules where channels overflowed with lava; the main body of the flow still retained its bedload of suspended xenoliths and continued to flow within the main channel.

The nodule banks associated with the main channel appear to represent flows erupted early in the eruption. The channel walls for most of their length are coated with successive thick lava veneers from later flows that did not form nodule beds. These later veneers obscure the channel margins of the earlier nodule-bearing flows. It appears, therefore, that nodule bank-forming conditions occurred only early in the eruption.

\section{Discussion}

The presence of banks of nodules from which lava drained over at least $4-5 \mathrm{~km}$ of the length of the flow indicates that the lava after eruption remained at or near Newtonian conditions for at least this distance. Thus the flow must have been moving at a high velocity. Eyewitness accounts (reviewed in McGetchin and Eichelberger 1975) report that the flow reached the ocean in less than an hour, although another report suggests twice that time (Brigham 1909). If these accounts are correct, such a transit time indicates an average velocity of about $16-20 \mathrm{~km} \mathrm{~h}^{-1}\left(4.5-5.5 \mathrm{~m} \mathrm{~s}^{-1}\right)$, and certainly $8-10 \mathrm{~km} \mathrm{~h}^{-1}$. However, the velocity of the flow would have decreased along its last few kilometers as the slopes decreased. Maximum velocities higher on the mountain may have been considerably greater; on the basis of plausible viscosities and eruption rates, McGetchin et al. (1976) estimated flow velocities of the order of $36-55 \mathrm{~km} \mathrm{~h}^{-1}\left(10-15 \mathrm{~m} \mathrm{~s}^{-1}\right)$.

The lava remained in a highly fluid state throughout the flow's descent to $6.5 \mathrm{~km}$ below the 'vents' near the repeater station. Even at lower sites, field observations show drainage of the nodule beds, overflow of channels by the lava and little evidence for the formation of a significant surficial crust. At the lowest nodule site, $4 \mathrm{~km}$ from the repeater station, the coating of lava around individual nodules approaches $1 \mathrm{~cm}$ thickness, 
implying a small increase in effective viscosity with distance from the eruptive vent.

The formation of a crust on the surface of an active flow can have an important effect on radiative losses and, thus, the flow's rheology (Crisp and Baloga 1990). Except for a few places where tubes developed at a late stage of flow emplacement, the entire Kaupulehu flow was channel-fed. Thus high temperature radiative heat losses must have occurred over a large percentage of the surface of the flow. Because the fluidity of the lava was retained so far downstream, high radiation rates from the upper surface suggest a combination of very high flow velocities and a rapid rate of renewal of the upper surface from the interior parts of the flow. The constraints provided by the field observations and our concept of nodule bed emplacement may imply even higher velocities than those suggested by McGetchin et al. (1976).

Other geological evidence also suggests high velocities of flow. Near the rift zone of Hualalai, a small cinder cone was partly overridden by the Kaupulehu flow; this cone is about $400 \mathrm{~m}$ from a vent and the lava flowed up the flank of the cone, overriding it $6.5 \mathrm{~m}$ above the surrounding level of the flow. On the basis of simple energy conservation considerations, we estimate the minimum velocity, $v$, of the flow impinging on the cone by

$v=\sqrt{2 h g}$

in which $h$ is the height risen and $g$ is gravitational acceleration. From this relation, the flow was moving at a velocity of at least $11 \mathrm{~m} \mathrm{~s}^{-1}\left(40 \mathrm{~km} \mathrm{~h}^{-1}\right)$. The post-emplacement thickness of the flow is probably less than that during flow, but even if we assume it was $2 \mathrm{~m}$ thicker we calculate a velocity of $9 \mathrm{~m} \mathrm{~s}^{-1}(\sim 33$ $\mathrm{km} \mathrm{h}^{-1}$ ). Other fluid dynamic factors that dissipate the energy of the flow (e.g. frictional forces or viscosity) suggest an even higher flow velocity than our minimum estimate.

Few historic eruptions of basaltic lava have produced flows that moved so fast. Another example on Hawaii is the 1823 Keiawa lava flow, erupted from the Great Crack of Kilauea's south-west rift zone; this flow is tholeiitic in composition and does not contain either xenoliths nor nodule beds similar to those of the Hualalai flow (Stearns 1926). Nevertheless, this flow must also have travelled at much greater than normal velocity; Ellis (1842) reports that canoes on the shore were overwhelmed before the Hawaiians could reach them and set out to sea. The 1823 Keiawa flow of Kilauea climbed nearly $10.5 \mathrm{~m}$ up the Lava Plastered Cones, which occur about $2 \mathrm{~km}$ downflow from the source (Stearns 1926). That these lava coatings were caused by high flow velocity is indicated by a directed spray of lava clots that occur on the far wall of the plastered cone; such a spray is explainable only by the sloshing and overspill of a relatively high velocity flow encountering a topographic obstacle. From these relations, we infer that the 1823 flow would have had a velocity of
$12-15 \mathrm{~m} \mathrm{~s}^{-1}\left(45-54 \mathrm{~km} \mathrm{~h}^{-1}\right)$, the lower figure assuming the flow was originally $2 \mathrm{~m}$ thicker than there is currently evidence for from tree molds. However, the 1823 flow, although relatively fluid compared with most basaltic lavas, probably had a higher effective viscosity than the Kaupulehu flow of 1801. Evidence for such a higher viscosity is in lava balls near the source fissure. These balls are accretionary features, consisting of a nucleus of older lava coated with a rind or multiple rinds of 1823 lava. However, unlike the nodules of the Kaupulehu flow, each layer has a thickness of more than $0.5 \mathrm{~mm}$ and is typically about $1 \mathrm{~cm}$. The greater fluidity of the Kaupulehu 1801 flow could have been a factor contributing to a possibly higher velocity of flow than the Keiawa 1823 flow.

Another fast-moving flow of basanitic composition was that of Nyiragongo in East Africa in 1977. This flow is thought to have travelled at over $28 \mathrm{~m} \mathrm{~s}^{-1}$ $\left(100 \mathrm{~km} \mathrm{~h}^{-1}\right)$ and is quoted as killing as many as 1000 people (Tazieff, 1976-1977, 1983), but the true value may be less than 500 . The high velocity flow resulted from rapid draining of a large lava lake in the central volcano.

Although eruptions of high effusion, low viscosity flows of lava are rare, two have occurred on Hawaii and one in Zaire during historical times. Indeed, the problem is, at the time of writing, topical, as concern is being expressed for the refugee camps on the southern slopes of Nyiragongo. Lava flows are generally considered to be hazardous to property, not to human life, but flows of this type in populated areas represent a serious and significant hazard.

Acknowledgements This work is supported by the NASA Planetary Geology and Geophysics Program. We thank the BP Bishop Estate and Doyal Davis for kindly arranging access to the field site on their property. We also thank David Clague and Scott Rowland for interesting discussions in the field; we have attempted to answere questions raised by them. W. Halliday, S. Werner, K. Kelley, D. Williams and S. Kadel are thanked for an underground survey. Donald Swanson, Harry Pinkerton, Lionel Wilson, David Clague, Richard Moore and an anonymous reviewer provided comments on the manuscript. This is Lunar and Planetary Institute Contribution Number 854, University of $\mathrm{Ha}$ waii SOEST Contribution Number 3829 and University of Hawaii HIGP Contribution 798.

\section{References}

Allen JRL (1970) Physical Processes of Sedimentation. George Allen and Unwin, London, $248 \mathrm{pp}$

Bohrson WA. Clague DA (1988) Origin of ultramafic xenoliths containing exsolved pyroxenes from Hualalai volcano. Hawaii. Contrib Mineral Petrol 100:139-155

Brigham WT (1909) The volcanoes of Kilauea and Mauna Loa. BP Bishop Mus Mem 2 (4). 222 pp

Chen C-H, Presnall DC, Stern RJ (1992) Petrogenesis of ultramafic xenoliths from the 1800 Kaupulehu flow. Hualalai volcano. Hawaii. J Petrol 33:163-202

Crisp J. Baloga S (1990) A model for lava flows with two thermal components. J Geophys Res 95 (B4): 1255-1270

Ellis W (1842) Polynesian Researches. Peter Jackson. Late Fisher, London 
Jackson ED. Clague DA (1982) Maß showing distribution of the nodule beds of the 1800-1801 Kaupulehu flow of Hualalai volcano, Hawaii. US Geol Surv Misc Field Stud Map MF-1355

Jackson ED. Clague DA, Engleman E. Friesen WB, Norton D (1981) Xenoliths in the alkalic basalt flows from Hualalai volcano, Hawaii. US Geol Surv Open File Rep 81-1031, 32 pp

McGetchin TR, Eichelberger J (1975) Emplacement of the 1801 Hualalai lava flow, Hawai. Solid Earth Geosciences Research Activities at LASL, Los Alamos Sci Lab Rep LA-5956-PR, $77-82$

McGetchin T, Widdicombe R, Neudecker J, Eichelberger J (1976) Emplacement of the 1801 Hualalai lava flow and laboratory simulation of Mauna Loa flow (abstract). EOS. Trans Am Geophys Union 57:344

Moore RB, Clague DA (1991) Geologic map of Hualalai volcano. Hawaii. US Geol Surv Map I-2213

Moore RB, Clague DA, Rubin M, Bohrson WA (1987) Hualalai volcano: a preliminary summary of geologic, petrologic, and geophysical data. In: Volcanism in Hawaii, US Geol Surv Prof Pap 1350:571-585

Richter DH. Murata KJ (1961) Xenolithic nodules in the 1800 1801 Kaupulehu flow of Hualalai volcano, Hawaii. US Geol Surv Prof Pap 424B:B215-B217

Sparks RSJ. Pinkerton H, Macdonald R (1977) The transport of xenoliths in magmas. Earth Planet Sci Lett 35:234-238

Stearns HT (1926) The Keiawa or 1823 lava flow from Kileauea volcano. Hawaii. J Geol 34:336-351

Tazieff $\mathrm{H}$ (1976-1977) An exceptional eruption: Mt. Nyragongo. Jan. 10th, 1977. Bull Volcanol 40:1-12

Tazieff $\mathrm{H}$ (1983) Estimating eruptive peril: some case histories. In: Tazieff H, Sabroux JC (eds) Forecasting Volcanic Events. Elsevier, Amsterdam 547-559

Editorial responsibility: H.-U. Schmincke 